\title{
CNVs Associated with Susceptibility to Cancers: A Mini-Review
}

\author{
Tomoko Furuya1, Yutaka Suehiro',3,4, Yukihisa Namiki ${ }^{3,4}$, Kohsuke Sasaki1,5 \\ ${ }^{1}$ Department of Pathology, Yamaguchi University Graduate School of Medicine, Ube, Japan \\ ${ }^{2}$ Department of Oncology and Laboratory Medicine, Yamaguchi University Graduate School of Medicine, Ube, \\ Japan \\ ${ }^{3}$ BraCare Genetics, Inc., Shimonoseki, Japan \\ ${ }^{4}$ Research Institute for Animal Science in Biochemistry and Toxicology (RIAS), Sagamihara, Japan \\ ${ }^{5} \mathrm{JCHO}$ Shimonoseki Medical Center, Shimonoseki, Japan \\ Email: tfuruya@yamaguchi-u.ac.jp
}

Received 4 March 2015; accepted 30 April 2015; published 6 May 2015

Copyright (C) 2015 by authors and Scientific Research Publishing Inc.

This work is licensed under the Creative Commons Attribution International License (CC BY).

http://creativecommons.org/licenses/by/4.0/

(c) (i) Open Access

\section{Abstract}

Copy number variations (CNVs) that are frequent in genome influence on susceptibility of various diseases including cancers. The present mini-review focuses on CNVs associated with susceptibility to the cancers. Since CNVs are different between cancer types, the analysis of the specific CNV makes it possible to estimate the susceptibility to the cancers of interest in individuals. Although it is true that available data on CNVs associated with cancer susceptibility are limited at present, accumulation of the data is accelerated with the research progression of CNVs in near future. Information on CNVs associated with cancer susceptibility is useful for not only cancer research but also personalized healthcare including cancer prevention.

\section{Keywords}

CNV, Cancer Susceptibility, Carcinogenesis, Cancer, Genome, Genomic Polymorphism

\section{Introduction}

In general, carcinogenesis guided by a multistep process is influenced by genetic and environmental factors, of which relative significance varies among individuals even with the same type of tumors [1] [2]. Cancers are categorized into "hereditary" or "sporadic" types based on individual hereditability. In hereditary cancers, hereditary genetic properties provide cells with high cancer susceptibility, and a contribution of environmental factors to cancer development is rather complementary [3] [4]. In sporadic cancers accounting for $>80 \%$ of cancers, in 
contrast, the environmental factors play more crucial roles than in hereditary cancers [5] [6]. A question remains, however, whether genetic backgrounds have a considerable effect on the susceptibility to sporadic cancers. In a chemical carcinogenesis model, carcinogenicity depends on genotypes of a mouse; chemical carcinogens cause cancer preferentially in mice with the particular genetic backgrounds [7]. In addition, a cohort study in twins reveals that, when one of a twin is affected by cancer, the other has the same type of the cancer at high incidence [6]. These findings suggest that the genetic backgrounds are associated with increasing or decreasing the risk of cancer by environmental factors such as exposure to carcinogens and that the susceptibility to sporadic cancers is influenced by genetic factors to various extents.

In terms of genetic backgrounds affecting susceptibility to sporadic cancers, single nucleotide polymorphisms (SNPs) may come uppermost. There are many reports on SNPs associated with risk for a variety of sporadic cancers, though their contributions to modifications of cancer risk are generally small [8]-[12]. Indeed, odds ratios of carcinogenesis estimated by SNPs are $1.1-1.2$ at most. The identification of more reliable markers capable of precise estimation of susceptibility to sporadic cancers in individuals is necessary for personalized healthcare including cancer prevention and early detection for the benefit of peoples. Recent technologies such as arraybased CGH (aCGH) and next generation sequencing (NGS) for comprehensive analysis of genome provide detailed information on structural differences between individuals, and facilitate the identification of CNVs associated with cancer development. Copy number variation (CNV) and copy number polymorphism (CNP) have been reported as a representative of large structural variations of genome by Sebat [13] and Iafrate [14], respectively in 2004, and now it is widely appreciated that the CNV (or CNP) is one of the most prevalent human genomic variations. Genome-wide association studies (GWAS) using these genetic methods have revealed that a part of CNVs play important roles in the development of complex pathological conditions such as birth defect, neurodevelopmental disorders, psychiatric diseases, and autoimmune diseases [15]-[17]. Furthermore, it has been accumulated as evidence that certain CNVs affect cancer susceptibility in individuals [17] [18]. The concept of CNVs associated with cancer susceptibility can explain well a difference in the frequency of sporadic cancers between individuals under the same environment. The CNVs associated with cancer susceptibility have been reported in dogs [19], mice [7] and chickens [20] as well as in human. The analysis of CNVs associated with cancer susceptibility CNVs allows us to estimate individual susceptibility to each type of cancers. Although data on CNVs associated with cancer susceptibility are still limited at present, further studies of the CNVs will bring about a new strategy against cancers. This review gives brief information on CNVs and highlights the associated susceptibility to sporadic cancers.

\section{Copy Number Variations (CNVs)}

Two copies of each autosomal region are normally found in genome, though there are many regions in genome where copy number is different between two persons [21]. These unique regions are referred as CNVs, which are one of the most representative structural genomic variations. The size of CNVs ranges from 1 kilobase to several megabases and the average size of CNVs is $2.9 \mathrm{~kb}$ [22]. CNVs are widely distributed throughout the human genome in which approximately 300,000 CNV regions have been identified [23]. CNVs are frequently found in pericentromeric and subteromeric regions where it is known as heterochromatin regions and late replicating regions [24] [25]. CNV regions totally occupy $12 \%$ of whole genome [26]. As much as $0.2 \%$ (six megabases) of the human genome varies in copy number between two individuals [27]. An average number of CNVs in individuals is 1100 [22]. CNV shared by more than $1 \%$ of a population is called copy number polymorphism (CNP) [13] [21]. CNPs are typically small in size (most are less than $10 \mathrm{~kb}$ in length), and they are often enriched for genes that encode proteins important in drug detoxification and immunity [28]-[31]. Interestingly, more than $40 \%$ of CNVs contain annotated genes implicated in cell growth and metabolism [22], and $40 \%$ of the cancer-related genes are disrupted by a CNV [17]. Generally, CNVs are stable and can be inherited. However, there are CNVs that arise spontaneously during meiosis or at an early stage in embryonic development. These are referred to as de novo CNVs, which may frequently give rise to phenotypic changes as compared with inherited ones [27] [32]. The presence of de novo (non-inherited) CNVs is verified in cases of homozygotic twin [33]. Mosaicism for CNV that can occur at any stage of development is not rare in human stem cells, somatic cells and induced pluripotent stem cells [34]-[37].

CNVs can be categorized into two types, common and rare variants, based on the frequency. Common variants ( $>1 \%$ population frequency) account for more than $80 \%$ of all CNVs [27]. The most of CNVs have noth- 
ing to do with cancer development, though a part of common CNVs is involved in the development of common diseases [27]. However, it is not simple to relate these CNVs to susceptibility of the disease, because usually they modestly affect the disease development. In contrast, rare CNVs ( $<1 \%$ population frequency) are frequently pathogenic and inducible in susceptibility to diseases including cancer due to the loss or disruption of tumor suppressor genes [18]. However, the underlying mechanisms of CNVs for cancer development still remain not to be clarified.

\section{CNVs Associated with Cancer Susceptibility}

Cancer susceptibility is different even between individuals exposed to the same carcinogen [7]. CNVs modulate (increase or decrease) the risk of sporadic cancers in individuals [38]. The CNVs associated with cancer susceptibility are also different between types of cancers. This indicates that the analysis of CNVs associated with the particular type of cancers allows us to estimate susceptibility to the cancer in individuals. Carcinogenesis is generally influenced by multiple genes. The interaction among CNVs associated with cancer susceptibility, usually, increases (or decreases) cancer risk on cells as anticipated as well as the interaction between CNVs and environment factors [39]-[41]. Rare CNVs are also involved in the development of the pediatric tumors including lymphoma and leukemia [42] [43]. Available data on CNVs related to cancer susceptibility are summarized in Table 1, in which large odds ratios are characteristic. CNVs related to cancer susceptibility have greater advantages in estimating cancer risk in individuals as compared with SNPs [8]-[12].

\subsection{Glioma}

Glioma is one of representative brain tumors. The copy number of a CNV located at 16q23.1-16q23.2 including WWOX is associated with susceptibility to glioma; the decrease in the copy number of the CNV increases a possibility of glioma development [44]. The odds ratio for glioma development is reported 1.21 for 1-copy loss and 1.94 for 2-copy loss.

Table 1. Cancers and cancer susceptible CNVs.

\begin{tabular}{|c|c|c|}
\hline Tumors & Chromosomal regions (gene) & OR \\
\hline Glioma & 16q23.1-q23.2 & $\begin{array}{l}1.21 \text { for } 1 \text {-copy deletion } \\
1.94 \text { for } 2 \text {-copy deletion }\end{array}$ \\
\hline Neuroblastoma & 1q21.1 (NBPF23) & 2.49 for deletion \\
\hline Nasopharyngeal carcinoma & 6p21.3 (MICA \& HCP5) & 18.92 in males \\
\hline Esophageal squamous cell carcinoma & 13q32.1 (ABCC4) & 3.36 for gain \\
\hline Gastric cancer & 5q22 (APC-exon9) & 0.48 for gain \\
\hline Colorectal cancer & $\begin{array}{l}\text { 4q13 (UGT2B17) } \\
\text { 12p12.3 (RERGL) }\end{array}$ & $\begin{array}{l}0.82 \text { for deletion } \\
1.66 \text { for gain }\end{array}$ \\
\hline Pancreatic cancer & $\begin{array}{c}\text { 6q13 } \\
\text { 5q22.2 (YTHDC2), loss }\end{array}$ & $\begin{array}{c}1.31 \text { for } 1 \text {-copy } \\
-\end{array}$ \\
\hline Lung cancer & $\begin{array}{l}\text { 1q32 (MAPKAPK2) } \\
\text { 16q23 (WWOX) }\end{array}$ & $\begin{array}{l}1.94 \text { for } 2 \text { - or } 3 \text {-copies } \\
1.39 \text { for } 0 \text { - or } 1 \text {-copy }\end{array}$ \\
\hline Breast cancer & $\begin{array}{l}\text { 15q26.3 (two CNVs) } \\
\text { 3p11.1 (EPHA3) }\end{array}$ & $\begin{array}{c}1.31 \text { for } 1 \text {-copy deletion } \\
1.76 \text { for } 2 \text {-copy deletion } \\
22.3 \text { for deletion } \\
1.96 \text { for deletion }\end{array}$ \\
\hline $\begin{array}{l}\text { Testicular tumor } \\
\text { (germ cell cancer) }\end{array}$ & 20q13.1-q13.2 (PTPN1) & 12.31 for deletion \\
\hline Prostate cancer & $\begin{array}{c}\text { 14q32.33 (IGHG3), gain } \\
\text { 2p24.3 } \\
\text { 22q11.23 (GSTT1) }\end{array}$ & $\begin{array}{c}- \\
1.31 \text { for deletion } \\
4.89 \text { for }>3 \text { copies }\end{array}$ \\
\hline Urinary bladder cancer & 1p13.3 (GSTM1) & 0.56 for two copies \\
\hline
\end{tabular}

This table does not capture all papers. 


\subsection{Neuroblastoma}

Neuroblastoma is representative pediatric tumors, and most of them arise sporadically. It is appreciated that specific genes including PHOX2B (paired-like homeobox 2b), ALK (anaplastic lymphoma receptor tyrosine kinase), and ATRX (alpha thalassemia/mental retardation syndrome X-linked) involve the development of neuroblastoma [45]. In addition, a CNV associated with susceptibility of neuroblastoma has been reported; a loss of a CNV at 1q21.1 (including NBPF23) increases the risk of sporadic neuroblastoma (OR = 2.49) [46] [47].

\subsection{Nasopharyngeal Carcinoma (NPC)}

NPC can occur in the throat of children and adults. The overrepresentation of CNVs has been reported in patients with nasopharyngeal carcinoma (NPC) compared with unaffected controls. A CNV located at 6p21.3 shows the highest association with NPC; a single-copy deletion of the CNV increases the risk of the disease [48]. In particular, the association of the CNV with an increased NPC risk is more specific in males with odds ratio of 18.92.

\subsection{Esophageal Squamous Cell Carcinoma (ESCC)}

ESCC is common in Asian countries including China and Japan. A CNV at 13q32.1 is associated with esophageal squamous cell carcinoma (ESCC) risk in Chinese persons [49]. A gain of a gene ABCC4 included in the CNV region activates oncogenic pathways, resulting in increase in the risk of ESCC (OR = 3.36). However, no reports on esophageal adenocarcinoma frequent in Western countries have been found as far as we have searched.

\subsection{Gastric Cancer}

Gastric cancer is one of the most frequent malignant tumors in Asia and South America, and many investigators have made a variety of studies of the disease. However, we have found one report on CNVs associated with gastric cancer. Tsai et al. reported that a loss of a CNV at $5 q 22$ including APC-exon 9 gives rise to a high risk of the disease [50].

\subsection{Colorectal Cancer (CRC)}

Colorectal cancer (CRC), which is frequently seen in advanced countries, has been studied well from a variety of aspects. However, data on CNVs associated with CRC susceptibility are limited at present. The deletion of UDP-glucuronosyltransferase (UGT) enzyme gene UGT2B17 at 4q13 is associated with a decreased CRC risk $(\mathrm{OR}=0.82)$ [51]. A gain of CNV at 12p12.3 including RERGL gene has been reported to increase the risk of CRC development even in persons with familial CRC [52]. In addition, CNVs may affect not only the risk of CRC but also the onset time of the disease [53].

\subsection{Pancreatic Cancer}

Pancreatic cancer is recognized as the most malignant tumor. Only a few studies are available on CNVs associated with susceptibility to pancreatic cancers [54] [55]. A CNV at 6q13 is implicated in pancreatic cancer susceptibility [54]. Persons with one copy of the CNV show higher risk of pancreatic cancer than those with two copies $(\mathrm{OR}=1.31)$. A CNV region containing YTHDC2 gene has been identified as a susceptible marker to pancreatic adenocarcinoma; one-copy loss of the CNV is found exclusively in patients with pancreatic cancer [55]. There is, however, controversy about the presence of CNVs associated with pancreatic cancer susceptibility [56].

\subsection{Lung Cancer}

Although the frequency of lung cancer is increasing in the world, a little has been reported about CNVs associated with susceptibility of lung cancer. The increase in copy number of a CNV at 1q32 encompassing the mitogen-activated protein kinase-activated protein kinase 2 (MAPKAPK2) promoter region increases the risk of lung adenocarcinoma [57]. The risk of lung cancer is higher in persons with four copies of the CNV than in 
those with two or three copies $(\mathrm{OR}=1.94)$. Another CNV associated with lung cancer is identified in Chinese [58]. The risk of lung cancer depends on the copy number of the CNV at 16q23 containing oxidoreductase (WWOX); the deletion genotype of the CNV increases the risk of lung cancer (OR = 1.39). Recently, Yang et al. have reported that $\geq 4$-copy of CNV in the nicotinic acetylcholine receptors (nAChRs) increase risk of lung cancer [59]. Lung cancers are classified into histological subtypes for the difference in therapeutic regimen. CNVs associated with the cancers may be different among histological subtypes, but such data have not been available.

\subsection{Breast Cancer}

Breast cancer risk assessment has been made [60] [61]. A deletion of a CNV in gene APOBEC3 increases breast cancer risk, with an odds ratio of 1.31 for a one-copy deletion and 1.76 for a two-copy deletion [62]. Copy numbers of CNVs on 1p36.12, 3q26.1, 15q26.3, and 22q12.3 considerably affect the susceptibility to breast cancer, with odds ratios of 3.3 to 15.6 [39]. Interestingly, the combination of two CNVs within 15q26.3 increases the accuracy for the prediction of breast cancer; $80.3 \%$ sensitivity, $80.6 \%$ specificity, $82.4 \%$ positive predictive value, $78.3 \%$ negative predictive value, and 22.3 of odds ratio [39]. CNVs also increase or decrease cancer susceptibility in patients with mutations in high-penetrance genes as well as in those with sporadic cancer. In cases of familial breast cancers, CNVs in RPA3, NBN (NBS1), MRE11A and CYP19A1 are involved in cancer development [63]. There are rare CNVs that are associated with early familial onset of breast cancers devoid of mutations of BRCA1/BRCA2 [64]. In individuals with familial BRCA1/2-negative breast and ovarian cancer, a $\mathrm{CNV}$ at 3p11.1 affects carcinogenesis; an intronic deletion in the EPHA3 receptor tyrosine kinase increases the fulminating risk of the disease $(\mathrm{OR}=1.96)$ [65]. The deletion variant of a $\mathrm{CNV}$ at 8p22 including mitochondrial tumor suppression gene 1 (MTUS1) also decreases the risk for familial breast cancer [66]. It may be natural to hypothesize that a certain CNV influences on molecular subtype of breast cancer. A deletion of a CNV at 10q24 including CYP2C19 is specifically associated with triple-negative breast cancer ( $\mathrm{OR}=2.83)$ [67].

\subsection{Testicular Cancer}

Data on CNVs associated with susceptibility to testicular tumors are very limited. A CNV at 20q13.1-q13.2 including gene PTPN1 has been reported to be associated with the risk of testicular germ cell cancer [41]. A deletion of the CNV increases the incidence of testicular germ cell cancer with odds ratio of 12.31.

\subsection{Prostate Cancer}

A copy number gain of a CNV at 14q32.33 encompassing IGHG3 gene increases prostate cancer risk in African American men [68]. The deletion of a CNV at 2p24.3 also increases prostate cancer risk and furthermore, it confers aggressive characteristics on prostate cancer $(\mathrm{OR}=1.31)$ [69]. In addition to these CNVs, a CNV at 22q11.23 including gene GSTT1affects the risk of prostate cancer; two and 3 or more copies of GSTT1 increase the risk of prostate cancer with odds ratios of 1.55 and 4.89, respectively [70].

\subsection{Urinary Bladder Cancer}

The copy number of a CNV at 1p13.3 including glutathione S-transferases Mu class 1 gene (GSTM1) is associated with the risk of the urinary bladder cancer; two copies of the CNV confer lower the risk compared to a single copy of it $(\mathrm{OR}=0.56)$ [71]. This is confirmed by another group $(\mathrm{OR}=0.66)$ [72].

\subsection{Lymphoma}

Cytogenetic studies are essential for a precise diagnosis in hematopoietic tumors such as lymphoma/leukemia. A few reports on CNVs associated with susceptibility to lymphoma are available. An association is found for duplications in a CNV located at 11q25 in diffuse large B-cell lymphoma (DLBCL) [73].

\section{Perspective}

Carcinogenesis results from the interaction of genetic and environmental factors and the weight of each factor for cancer development may be greatly different between hereditary and sporadic cancers and even between the same types of tumors. It is thought that the genetic factors are less critical for sporadic cancers than for heredi- 
tary cancer. However, this hypothesis has been changed into a view that genetic factors involve deeply in development of not only hereditary cancers but also sporadic cancers. Genetic factors modulate functions of environmental factors, which are essential for sporadic cancer development. ACNV has recently drawn attention as a reliable marker of cancer susceptibility. Different CNVs are associated with different cancers, as mentioned above. Furthermore, the combination of a few CNVs involved in carcinogenesis can elevate the accuracy in the estimation of individual cancer susceptibility. Analyzing the CNVs allows us to score the personalized risk to the relevant cancer. The odds ratio estimated by the CNVs is much greater than that by SNPs. Available data on CNVs related to cancer susceptibility are very limited at present, and the CNVs have not yet been incorporated into the standard assay systems of cancer risk prediction.

Extensive validation and prospective cohort studies should be conducted in large homogeneous populations to identify reliable CNVs associated with cancer susceptibility, and such studies will provide new horizons in human health-care including cancer prevention. The molecular mechanisms of carcinogenesis affected by the CNVs associated with cancer susceptibility will be clarified by further enthusiastic investigations.

\section{Acknowledgements}

This work was supported in part by the New Energy and Industrial Technology Development Organization (NEDO) of Japan and by Grants-in-Aid for Scientific Research (No. 25460458) from the Ministry of Education, Science, Sports and Culture of Japan.

\section{References}

[1] Gamazon, E.R., Huang, R.S., Dolan, M.E. and Cox, N.J. (2011) Copy Number Polymorphisms and Anticancer Pharmacogenomics. Genome Biology, 12, R46. http://dx.doi.org/10.1186/gb-2011-12-5-r46

[2] Quigley, D. and Balmain, A. (2009) Systems Genetics Analysis of Cancer Susceptibility: From Mouse Modelsto Humans. Nature Reviews Genetics, 10, 651-657. http://dx.doi.org/10.1038/nrg2617

[3] Borecki, I.B. and Province, M.A. (2008) Linkage and Association: Basic Concepts. Advances in Genetics, 60, 51-74. http://dx.doi.org/10.1016/S0065-2660(07)00403-8

[4] Galvan, A., Ioannidis, J.P. and Dragani, TA. (2010) Beyond Genome-Wide Association Studies: Genetic Heterogeneity and Individual Predisposition to Cancer. Trends in Genetics, 26,132-141. http://dx.doi.org/10.1016/j.tig.2009.12.008

[5] Czene, K., Lichtenstein, P. and Hemminki, K. (2002) Environmental and Heritable Causes of Cancer among 9.6 Million Individuals in the Swedish Family-Cancer Database. International Journal of Cancer, 99, 260-266. http://dx.doi.org/10.1002/ijc.10332

[6] Lichtenstein, P., Holm, N.V., Verkasalo, P.K., Iliadou, A., Kaprio, J., Koskenvuo, M., Pukkala, E., Skytthe, A. and Hemminki, K. (2000) Environmental and Heritable Factors in the Causation of Cancer-Analyses of Cohorts of Twins from Sweden, Denmark, and Finland. The New England Journal of Medicine, 343, 78-85. http://dx.doi.org/10.1056/NEJM200007133430201

[7] Meunier, C., Van Der Kraak, L., Turbide, C., Groulx, N., Labouba, I., Cingolani, P., Blanchette, M., Yeretssian, G., Mes-Masson, A.M., Saleh, M., Beauchemin, N. and Gros. P. (2013) Positional Mapping and Candidate Gene Analysis of the Mouse Ccs3 Locus That Regulates Differential Susceptibility to Carcinogen-Induced Colorectal Cancer. PLoS One, 8, e58733. http://dx.doi.org/10.1371/journal.pone.0058733

[8] Zhang, B., Beeghly-Fadiel, A., Long, J. and Zheng, W. (2011) Genetic Variants Associated with Breast-Cancer Risk: Comprehensive Research Synopsis, Meta-Analysis, and Epidemiological Evidence. The Lancet Oncology Journal, 12, 477-488. http://dx.doi.org/10.1016/S1470-2045(11)70076-6

[9] Choy, K., Setlur, S., Lee, C. and Lau, T. (2010) The Impact of Human Copy Number Variation on a New Era of Genetic Testing. BJOG, 117, 391-397. http://dx.doi.org/10.1111/j.1471-0528.2009.02470.x

[10] Kim, H.C., Lee, J.Y., Sung, H., Choi, J.Y., Park, S.K., Lee, K.M., Kim, Y.J., Go, M.J., Li, L., Cho, Y.S., Park, M., Kim, D.J., Oh, J.H., Kim, J.W., Jeon, J.P., Jeon, S.Y., Min, H., Kim, H.M., Park, J., Yoo, K.Y., Noh, D.Y., Ahn, S.H., Lee, M.H., Kim, S.W., Lee, J.W., Park, B.W., Park, W.Y., Kim, E.H., Kim, M.K., Han, W., Lee, S.A., Matsuo, K., Shen, C.Y., Wu, P.E., Hsiung, C.N., Lee, J.Y., Kim, H.L., Han, B.G. and Kang, D. (2012) A Genome-Wide Association Study Identifies a Breast Cancer Risk Variant in ERBB4 at 2q34: Results from the Seoul Breast Cancer Study. Breast Cancer Research, 14, R56. http://dx.doi.org/10.1186/bcr3158

[11] Zheng, Y., Ogundiran, T.O., Falusi, A.G., Nathanson, K.L., John, E.M., Hennis, A.J., Ambs, S., Domchek, S.M., Rebbeck, T.R., Simon, M.S., Nemesure, B., Wu, S.Y., Leske, M.C., Odetunde, A., Niu, Q., Zhang, J., Afolabi, C., Gamazon, E.R., Cox, N.J., Olopade, C.O., Olopade, O.I. and Huo, D. (2013) Fine Mapping of Breast Cancer Genome-Wide 
Association Studies Loci in Women of African Ancestry Identifies Novel Susceptibility Markers. Carcinogenesis, 34, 1520-1528. http://dx.doi.org/10.1093/carcin/bgt090

[12] Dong, L.M., Potter, J.D., White, E., Ulrich, C.M., Cardon, L.R. and Peters, U. (2008) Genetic Susceptibility to Cancer: The Role of Polymorphisms in Candidate Genes. Journal of the American Medical Association, 299, 2423-2436. http://dx.doi.org/10.1001/jama.299.20.2423

[13] Sebat, J., Lakshmi, B., Roge, J., Alexander, J., Young, J., Lundin, P., Månér, S., Massa, H., Walker, M., Chi, M., Navin, N., Lucito, R., Healy, J., Hicks, J., Ye, K., Reiner, A., Gilliam, T.C., Trask, B., Patterson, N., Zetterberg, A. and Wigler, M. (2004) Large-Scale Copy Number Polymorphism in the Human Genome. Science, 305, 525-528. http://dx.doi.org/10.1126/science.1098918

[14] Iafrate, A.J., Feuk, L., Rivera, M.N., Listewnik, M.L., Donahoe, P.K., Qi, Y., Scherer, S.W. and Lee, C. (2004) Detection of Large-Scale Variation in the Human Genome. Nature Genetics, 36, 949-951. http://dx.doi.org/10.1038/ng1416

[15] Olsson, L.M. and Holmdahl, R. (2012) Copy Number Variation in Autoimmunity_-Importance Hidden in Complexity? European Journal of Immunology, 42, 1969-1976. http://dx.doi.org/10.1002/eji.201242601

[16] Malhotra, D. and Sebat, J. (2012) CNVs: Harbingers of a Rare Variant Revolution in Psychiatric Genetics. Cell, 148, 1223-1241. http://dx.doi.org/10.1016/j.cell.2012.02.039

[17] Almal, S.H. and Padh, H. (2012) Implications of Gene Copy-Number Variation in Health and Diseases. Journal of Human Genetics, 57, 6-13. http://dx.doi.org/10.1038/jhg.2011.108

[18] Kuiper, R.P., Ligtenberg, M.J., Hoogerbrugge, N. and Geurts van Kessel, A. (2010) Germline Copy Number Variation and Cancer Risk. Current Opinion in Genetics Development, 20, 282-289. http://dx.doi.org/10.1016/j.gde.2010.03.005

[19] Karyadi, D.M., Karlins, E., Decker, B., vonHoldt, B.M., Carpintero-Ramirez, G., Parker, H.G., Wayne, R.K. and Ostrander, E.A. (2013) A Copy Number Variant at the KITLG Locus Likely Confers Risk for Canine Squamous Cell Carcinoma of the Digit. PLoS Genetics, 9, e1003409. http://dx.doi.org/10.1371/journal.pgen.1003409

[20] Luo, J., Yu, Y., Mitra, A., Chang, S., Zhang, H.M., Liu, G., Yang, N. and Song, J.Z. (2013) Genome-Wide Copy Number Variant Analysis in Inbred Chickens Lines with Different Susceptibility to Marek's Disease. Genes, Genomes, Genetics, 3, 217-223. http://dx.doi.org/10.1534/g3.112.005132

[21] Feuk, L., Scherer, S.W. and Carson, A.R. (2008) Structural Variation in the Human Genome. Nature Reviews Genetics, 7, 85-97. http://dx.doi.org/10.1038/nrg1767

[22] Conrad, D.F., Pinto, D., Redon, R., Feuk, L., Gokcumen, O., Zhang, Y., Aerts, J., Andrews, T.D., Barnes, C., Campbell, P., Fitzgerald, T., Hu, M., Ihm, C.H., Kristiansson, K., Macarthur, D.G., Macdonald, J.R., Onyiah, I., Pang, A.W., Robson, S., Stirrups, K., Valsesia, A., Walter, K., Wei, J., Carter, N.P., Lee, C., Scherer, S.W. and Hurles, M.E. (2010) Origins and Functional Impact of Copy Number Variation in the Human Genome. Nature, 464, 704-712. http://dx.doi.org/10.1038/nature08516

[23] Valsesia, A., Macé, A., Jacquemont, S., Beckmann, J.S. and Kutalik, Z. (2013) The Growing Importance of CNVs: New Insights for Detection and Clinical Interpretation. Frontiers in Genetics, 4, 92. http://dx.doi.org/10.3389/fgene.2013.00092

[24] Bailey, J.A. and Eichler, E.E. (2006). Primate Segmental Duplications: Crucibles of Evolution, Diversity and Disease. Nature Reviews Genetics 7, 552-564. http://dx.doi.org/10.1038/nrg1895

[25] Juan, D., Rico, D., Marques-Bonet, T., Fernández-Capetillo, O. and Valencia, A. (2013) Late-Replicating CNVs as a Source of New Genes. Biology Open, 2, 1402-1411. http://dx.doi.org/10.1242/bio.20136924

[26] Carter, N.P. (2007) Methods and Strategies for Analyzing Copy Number Variation Using DNA Microarrays. Nature Genetics, 39, S16-S21. http://dx.doi.org/10.1038/ng2028

[27] McCarroll, S.A., Kuruvilla, F.G., Korn, J.M., Cawley, S., Nemesh, J., Wysoker, A., Shapero, M.H., de Bakker, P.I., Maller, J.B., Kirby, A., Elliott, A.L., Parkin, M., Hubbell, E., Webster, T., Mei, R., Veitch, J., Collins, P.J., Handsaker, R., Lincoln, S., Nizzari, M., Blume, J., Jones, K.W., Rava, R., Daly, M.J., Gabriel, S.B. and Altshuler, D. (2008) Integrated Detection and Population-Genetic Analysis of SNPs and Copy Number Variation. Nature Genetics, 40, 11661174. http://dx.doi.org/10.1038/ng.238

[28] Goetz, M.P., Knox, S.K., Suman, V.J., Rae, J.M., Safgren, S.L., Ames, M.M., Visscher, D.W., Reynolds, C., Couch, F.J., Lingle, W.L., Weinshilboum, R.M., Fritcher, E.G., Nibbe, A.M., Desta, Z., Nguyen, A., Flockhart, D.A., Perez, E.A. and Ingle, J.N. (2007) The Impact of Cytochrome P450 2D6 Metabolism in Women Receiving Adjuvant Tamoxifen. Breast Cancer Research and Treatment, 101, 113-121. http://dx.doi.org/10.1007/s10549-006-9428-0

[29] Gasche, Y., Daali, Y., Fathi, M., Chiappe, A., Cottini, S., Dayer, P. and Desmeules, J. (2004) Codeine Intoxication Associated with Ultrarapid CYP2D6 Metabolism. The New England Journal of Medicine, 351, 2827-2831. http://dx.doi.org/10.1056/NEJMoa041888

[30] Malaiyandi, V., Sellers, E.M. and Tyndale, R.F. (2005) Implications of CYP2A6 Genetic Variation for Smoking Behaviors and Nicotine Dependence. Clinical Pharmacology \& Therapeutics, 77, 145-158. 
http://dx.doi.org/10.1016/j.clpt.2004.10.011

[31] Eichler, E.E. (2008) Copy Number Variation and Human Disease. Nature Education, 1, 1.

[32] Merikangas, A.K., Corvin, A.P. and Gallagher, L. (2009) Copy-Number Variants in Neurodevelopmental Disorders: Promises and Challenges. Trends in Genetics, 25, 536-544. http://dx.doi.org/10.1016/j.tig.2009.10.006

[33] Bruder, C.E., Piotrowski, A., Gijsbers, A.A., Andersson, R., Erickson, S., Diaz de Ståhl, T., Menzel, U., Sandgren, J., von Tell, D., Poplawski, A., Crowley, M., Crasto, C., Partridge, E.C., Tiwari, H, Allison, D.B., Komorowski, J., van Ommen, G.J., Boomsma, D.I., Pedersen, N.L., den Dunnen, J.T., Wirdefeldt, K. and Dumanski, J.P. (2008) Phenotypically Concordant and Discordant Monozygotic Twins Display Different DNA Copy-Number-Variation Profiles. The American Journal of Human Genetics, 82, 763-771. http://dx.doi.org/10.1016/j.ajhg.2007.12.011

[34] Liang, Q., Conte, N., Skarnes, W.C. and Bradley, A. (2006) Extensive Genomic Copy Number Variation in Embryonic Stem Cells. Proceedings of the National Academy of Sciences of the United States of America, 105, 17453-17456. http://dx.doi.org/10.1073/pnas.0805638105

[35] Abyzov, A., Mariani, J., Palejev, D., Zhang, Y., Haney, M.S., Tomasini, L., Ferrandino, A.F., Rosenberg Belmaker, L.A., Szekely, A., Wilson, M., Kocabas, A., Calixto, N.E., Grigorenko, E.L., Huttner, A., Chawarska, K., Weissman, S., Urban, A.E., Gerstein, M. and Vaccarino, F.M. (2012) Somatic Copy Number Mosaicism in Human Skin Revealed by Induced Pluripotent Stem Cells. Nature, 492, 438-442. http://dx.doi.org/10.1038/nature11629

[36] Poduri, A., Evrony, G.D., Cai, X. and Walsh, C.A. (2013) Somatic Mutation, Genomic Variation, and Neurological Disease. Science, 341, Article ID: 1237758. http://dx.doi.org/10.1126/science.1237758

[37] Carvalho, C.M., Pehlivan, D., Ramocki, M.B., Fang, P., Alleva, B., Franco, L.M., Belmont, J.W., Hastings, P.J. and Lupski, J.R. (2013) Replicative Mechanisms for CNV Formation Are Error Prone. Nature Genetics, 45, 1319-1326. http://dx.doi.org/10.1038/ng.2768

[38] Krepischi, A.C.V., Pearson, P.L. and Rosenberg, C. (2012) Germline Copy Number Variations and Cancer Predisposition. Future Oncology, 8, 441-450. http://dx.doi.org/10.2217/fon.12.34

[39] Suehiro, Y., Okada, T., Shikamoto, N., Zhan, Y., Sakai, K., Okayama, N., Nishioka, M., Furuya, T., Oga, A., Kawauchi, S., Maeda, N., Tamesa, M., Nagashima, Y., Yamamoto, S., Oka, M., Hinoda, Y. and Sasaki, K. (2013) Germline Copy Number Variations Associated with Breast Cancer Susceptibility in a Japanese Population. Tumor Biology, 34, 947-952. http://dx.doi.org/10.1007/s13277-012-0630-x

[40] Demichelis, F. and Stanford, J.L. (2015) Genetic Predisposition to Prostate Cancer: Update and Future Perspectives. Urologic Oncology, 33, 75-84. http://dx.doi.org/10.1016/j.urolonc.2014.04.021

[41] Edsgärd, D., Dalgaard, M.D., Weinhold, N., Wesolowska-Andersen, A., Rajpert-De Meyts, E., Ottesen, A.M., Juul, A., Skakkebæk, N.E., Skøt Jensen. T., Gupta. R., Leffers, H. and Brunak, S. (2013) Genome-Wide Assessment of the Association of Rare and Common Copy Number Variations to Testicular Germ Cell Cancer. Frontiers in Endocrinology, 4, 2. http://dx.doi.org/10.3389/fendo.2013.00002

[42] Krepischi, A.C., Capelli, L.P., Silva, A.G., de Araújo, E.S.S., Pearson, P.L., Heck, B., da Costa, C.M.L., de Camargo, B. and Rosenberg, C. (2014) Large Germline Copy Number Variations as Predisposing Factor in Childhood Neoplasms. Future Oncology, 10, 1627-1633. http://dx.doi.org/10.2217/fon.14.41

[43] Hopman, S., Merks, J., Eussen, H., Douben, H., Snijder, S., Hennekam, R., de Klein, A. and Caron, H. (2013) Structural Genome Variations in Individuals with Childhood Cancer and Tumour Predisposition Syndromes. European Journal of Cancer, 49, 2170-2178. http://dx.doi.org/10.1016/j.ejca.2013.02.002

[44] Yu, K., Fan, J., Ding, X., Li, C., Wang, J., Xiang, Y. and Wang, Q.S. (2014) Association Study of a Functional Copy Number Variation in the WWOX Gene with Risk of Gliomas among Chinese People. International Journal of Cancer, 135, 1687-1691. http://dx.doi.org/10.1002/ijc.28815

[45] Sridhar, S., Al-Moallem, B., Kamal, H., Terrile, M. and Stallings, R.L. (2013) New Insights into the Genetics of Neuroblastoma. Molecular Diagnosis \& Therapy, 17, 63-69. http://dx.doi.org/10.1007/s40291-013-0019-6

[46] Diskin, S.J. (2009) Copy Number Variation at 1q21.1 Associated with Neuroblastoma. Nature, 459, 987-991. http://dx.doi.org/10.1038/nature08035

[47] Capasso, M. and Diskin, S.J. (2010) Genetics and Genomics of Neuroblastoma. Cancer Genetics, 155, 65-84. http://dx.doi.org/10.1007/978-1-4419-6033-7_4

[48] Tse, K.P., Su, W.H., Yang, M.L., Cheng, H.Y., Tsang, N.M., Chang, K.P., Hao, S.P., Shugart, Y.Y. and Chang. Y.S. (2011) A Gender-Specific Association of CNV at 6p21.3 with NPC Susceptibility. Human Molecular Genetics, 20, 2889-2896. http://dx.doi.org/10.1093/hmg/ddr191

[49] Sun, Y.L., Shi, N., Lu, H.Z., Zhang, J.Q., Ma, Y.L., Qiao, Y.Y., Mao, Y.H., Jia, K., Han, L.F., Liu, F., Li, H.X., Lin, Z.W., Li, X.M. and Zhao, X.H. (2014) ABCC4 Copy Number Variation Is Associated with Susceptibility to Esophageal Squamous Cell Carcinoma. Carcinogenesis, 35, 1941-1950. http://dx.doi.org/10.1093/carcin/bgu043

[50] Tsai, P.C., Huang, S.W., Tsai, H.L., Ma, C.J., Hou, M.F., Yang, I.P., Wang, Y.S., Juo, S.H. and Wang, J.Y. (2014) The 
Association between DNA Copy Number Aberrations at Chromosome 5q22 and Gastric Cancer. PLoS ONE, 9, e106624. http://dx.doi.org/10.1371/journal.pone.0106624

[51] Angstadt, A.Y., Berg, A., Zhu, J.J., Miller, P., Hartman, T.J., Lesko, S.M., Muscat, J.E., Lazarus, P. and Gallagher, C.J. (2013) The Effect of Copy Number Variation in the Phase II Detoxification Genes UGT2B17 and UGT2B28 on Colorectal Cancer Risk. Cancer, 119, 2477-2485. http://dx.doi.org/10.1002/cncr.28009

[52] Yang, R.X., Chen, B.W., Pfütze, K., Buch, S., Steinke, V., Holinski-Feder, E., Stöcker, S., von Schönfels, W., Becker, T., Schackert, H.K., Royer-Pokora, B., Kloor, M., Schmiegel, W.H., Büttner, R., Engel, C., LascorzPuertolas, J., Försti, A., Kunkel, N., Bugert, P., Schreiber, S., Krawczak, M., Schafmayer, C., Propping, P., Hampe, J., Hemminki, K. and Burwinkel, B. (2014) Genome-Wide Analysis Associates Familial Colorectal Cancer with Increases in Copy Number Variations and a Rare Structural Variation at 12p12.3. Carcinogenesis, 35, 315-323. http://dx.doi.org/10.1093/carcin/bgt344

[53] Berg, M., Agesen, T.H., Thiis-Evensen, E., INFAC-Study Group, Merok, M.A., Teixeira, M.R., Vatn, M.H., Nesbakken, A., Skotheim, R.I. and Lothe, R.A. (2010) Distinct High Resolution Genome Profiles of Early Onset and Late Onset Colorectal Cancer Integrated with Gene Expression Data Identify Candidate Susceptibility Loci. Molecular Cancer, 9, 100. http://dx.doi.org/10.1186/1476-4598-9-100

[54] Huang, L.M., Yu, D.K., Wu, C., Zhai, K., Jiang, G.L., Cao, G.W., Wang, C.Y., Liu, Y., Sun, M.H., Li, Z.S., Tan, W. and Lin, D.X. (2012) Copy Number Variation at 6q13 Functions as a Long-Range Regulator and Is Associated with Pancreatic Cancer Risk. Carcinogenesis, 33, 94-100. http://dx.doi.org/10.1093/carcin/bgr228

[55] Fanale, D., Iovanna, J.L., Calvo, E.L., Berthezene, P., Belleau, P., Dagorn, J.C., Bronte, G., Cicero, G., Bazan, V., Rolfo, C., Santini, D. and Russo, A. (2014) Germline Copy Number Variation in the YTHDC2 Gene: Does It Have a Role in Finding a Novel Potential Molecular Target Involved in Pancreatic Adenocarcinoma Susceptibility? Expert Opinion on Therapeutic Targets, 18, 841-850.

[56] Willis, J.A., Mukherjee, S., Orlow, I., Viale, A., Offit, K., Kurtz, R.C., Olson, S.H. and Klein, R.J. (2014) GenomeWide Analysis of the Role of Copy-Number Variation in Pancreatic Cancer Risk. Frontiers in Genetics, 5, 29. http://dx.doi.org/10.3389/fgene.2014.00029

[57] Liu, B., Yang, L., Huang, B.F., Cheng, M., Wang, H., Li, Y.Y., Huang, D.S., Zheng, J., Li, Q.C., Zhang, X., Ji, W.D., Zhou, Y.F. and Lu, J.C. (2012) A Functional Copy-Number Variation in MAPKAPK2 Predicts Risk and Prognosis of Lung Cancer. The American Journal of Human Genetics, 91, 384-390. http://dx.doi.org/10.1016/j.ajhg.2012.07.003

[58] Yang, L., Liu, B., Huang, B.F., Deng, J.Q., Li, H.B., Yu, B.L., Qiu, F.M., Cheng, M., Wang, H., Yang, R.R., Yang, X.R., Zhou, Y.F. and Lu, J.C. (2013) A Functional Copy Number Variation in the WWOX Gene Is Associated with Lung Cancer Risk in Chinese. Human Molecular Genetics, 22, 1886-1894. http://dx.doi.org/10.1093/hmg/ddt019

[59] Yang, L., Lu, X.X., Qiu, F.M., Fang, W.X., Zhang, L.S., Huang, D.S., Xie, C.L., Zhong, N.S., Ran, P.X., Zhou, Y.F. and Lu, J.C. (2014) Duplicated Copy of CHRNA7 Increases Risk and Worsens Prognosis of COPD and Lung Cancer. European Journal of Human Genetics, in press. http://dx.doi.org/10.1038/ejhg.2014.229

[60] Fischer, C., Kuchenbäcker, K., Engel, C., Zachariae, S., Rhiem, K., Meindl, A., Rahner, N., Dikow, N., Plendl, H., Debatin, I., Grimm, T., Gadzicki, D., Flöttmann, R., Horvath, J., Schröck, E., Stock, F., Schäfer, D., Schwaab, I., Kartsonaki, C., Mavaddat, N., Schlegelberger, B., Antoniou, A.C. and Schmutzler, R. (2013) German Consortium for Hereditary Breast and Ovarian Cancer: Evaluating the Performance of the Breast Cancer Genetic Risk Models BOADICEA, IBIS, BRCAPRO and Claus for Predicting BRCA1/2 Mutation Carrier Probabilities: A Study Based on 7352 Families from the German Hereditary Breast and Ovarian Cancer Consortium. Journal of Medical Genetics, 50, 360-367. http://dx.doi.org/10.1136/jmedgenet-2012-101415

[61] MacInnis, R.J., Bickerstaffe, A., Apicella, C., Dite, G.S., Dowty, J.G., Aujard, K., Phillips, K.A., Weideman, P., Lee, A., Terry, M.B., Giles, G.G., Southey, M.C., Antoniou, A.C. and Hopper, J.L. (2013) Prospective Validation of the Breast Cancer Risk Prediction Model BOADICEA and a Batch-Mode Version BOADICEACentre. British Journal of Cancer, 109, 1296-1301. http://dx.doi.org/10.1038/bjc.2013.382

[62] Long, J., Delahanty, R.J., Li, G.L., Gao, Y.T., Lu, W., Cai, Q.Y., Xiang, Y.B., Li, C., Ji, B.T., Zheng, Y., Ali, S., Shu, X.O. and Zheng, W. (2013) A Common Deletion in the APOBEC3 Genes and Breast Cancer Risk. Journal of the National Cancer Institute, 105, 573-579. http://dx.doi.org/10.1093/jnci/djt018

[63] Masson, A.L., Talseth-Palmer, B.A., Evans, T.J., Grice, D.M., Hannan, G.N. and Scott, R.J. (2014) Expanding the Genetic Basis of Copy Number Variation in Familial Breast Cancer. Hereditary Cancer in Clinical Practice, 12, 15. http://dx.doi.org/10.1186/1897-4287-12-15

[64] Krepischi, A.C., Achatz, M.I., Santos, E.M., Costa, S.S., Lisboa, B.C., Brentani, H., Santos, T.M., Gonçalves, A., Nóbrega, A.F., Pearson, P.L., Vianna-Morgante, A.M., Carraro, D.M., Brentani, R.R. and Rosenberg, C. (2012) Germline DNA Copy Number Variation in Familial and Early-Onset Breast Cancer. Breast Cancer Research, 14, R24. http://dx.doi.org/10.1186/bcr3109

[65] Kuusisto, K.M., Akinrinade, O., Vihinen, M., Kankuri-Tammilehto, M., Laasanen, S.L. and Schleutker, J. (2013) Copy 
Number Variation Analysis in Familial BRCA1/2-Negative Finnish Breast and Ovarian Cancer. PLoS ONE, 8, e71802. http://dx.doi.org/10.1371/journal.pone.0071802

[66] Frank, B., Bermejo, J.L., Hemminki, K., Sutter, C., Wappenschmidt, B., Meindl, A., Kiechle-Bahat, M., Bugert, P., Schmutzler, R.K., Bartram, C.R. and Burwinkel, B. (2007) Copy Number Variant in the Candidate Tumor Suppressor Gene MTUS1 and Familial Breast Cancer Risk. Carcinogenesis, 28, 1442-1445. http://dx.doi.org/10.1093/carcin/bgm033

[67] Tervasmäki, A., Winqvist, R., Jukkola-Vuorinen, A. and Pylkäs, K. (2014) Recurrent CYP2C19 Deletion Allele Is Associated with Triple-Negative Breast Cancer. BMC Cancer, 14, 902. http://dx.doi.org/10.1186/1471-2407-14-902

[68] Ledet, E.M., Hu, X.F., Sartor, O., Rayford, W., Li, M. and Mandal, D. (2013) Characterization of Germline Copy Number Variation in High-Risk African American Families with Prostate Cancer. The Prostate, 73, 614-623. http://dx.doi.org/10.1002/pros.22602

[69] Liu, W.N., Sun, J.S., Li, G., Zhu, Y., Zhang, S., Kim, S.T., Sun, J.L., Wiklund, F., Wiley, K., Isaacs, S.D., Stattin, P., $\mathrm{Xu}$, J., Duggan, D., Carpten, J.D., Isaacs, W.B., Grönberg, H., Zheng, S.L. and Chang, B.L. (2009) Association of a Germ-Line Copy Number Variation at 2p24.3 and Risk for Aggressive Prostate Cancer. Cancer Research, 69, 21762179. http://dx.doi.org/10.1158/0008-5472.CAN-08-3151

[70] Emeville, E., Broquère, C., Brureau, L., Ferdinand, S., Blanchet, P., Multigner, L. and Romana, M. (2014) Copy Number Variation of GSTT1 and GSTM1 and the Risk of Prostate Cancer in a Caribbean Population of African Descent. PLoS ONE, 9, e107275. http://dx.doi.org/10.1371/journal.pone.0107275

[71] Zhang, X.M., Lin, J., Wu, X.F., Lin, Z.N., Ning, B.T., Kadlubar, S. and Kadlubar, F.F. (2012) Association between GSTM1 Copy Number, Promoter Variants and Susceptibility to Urinary Bladder Cancer. International Journal of Molecular Epidemiology and Genetics, 3, 228-236.

[72] Marenne, G., Real, F.X., Rothman, N., Rodríguez-Santiago, B., Pérez-Jurado, L., Kogevinas, M., García-Closas, M., Silverman, D.T., Chanock, S.J., Génin, E. and Malats, N. (2012) Genome-Wide CNV Analysis Replicates the Association between GSTM1 Deletion and Bladder Cancer: A Support for Using Continuous Measurement from SNP-Array Data. BMC Genomics, 13, 326. http://dx.doi.org/10.1186/1471-2164-13-326

[73] Conde, L., Riby, J., Zhang, J.Q., Bracci, P.M. and Skibola, C.F. (2014) Copy Number Variation Analysis on a NonHodgkin Lymphoma Case-Control Study Identifies an 11q25 Duplication Associated with Diffuse Large B-Cell Lymphoma. PLOS ONE, 9, e105382. http://dx.doi.org/10.1371/journal.pone.0105382 